\title{
Trade Openness, Economic Growth and Convergence: Evidence from Selected Asian Countries
}

\author{
MOHD ZAINI ABDUL KARIM \\ Faculty of Economics \\ University Utara Malaysia.
}

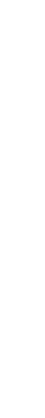

ABSTRACT

It is argued that countries, which adopt an open economic policy, enjoy faster economic growth than countries which do not, suggesting that "trade openness" can spur economic growth. However, the issue is whether the positive impact of trade openness to economic growth varies across countries. Hence, the objective of this paper is to determine whether the effect of openness to trade on economic growth varies across the region in Asia. To achieve this objective, panel data regressions were employed (1) estimate the growth equation. Empirical results indicated that "trade openness" does have a positive effect on economic growth and the marginal benefit from improved openness is somewhat higher for East Asian Economies relative to other Asian economies.

$\varepsilon$

5

\section{ABSTRAK}

Negara-negara yang mengamalkan dasar ekonomi terbuka dikatakan mencapai pertumbuhan ekonomi lebih pesat berbanding dengan negara-negara mengamalkan dasar ekonomi tertutup. Ini menunjukkan ahawa keterbukaan perdagangan meningkatkan pertumbuhan ekonomi. Walau bagaimanapun, isu sama ada kesan positif keterbukaan ekonomi terhadap pertumbuhan ekonomi adalah berbeza antara negara-negara. Artikel ini menganalisis sama ada keterbukaan perdagangan mempengaruhi pertumbuhan ekonomi secara berbeza antara wilayah-wilayah di Asia. Bagi mencapai objektif ini, regresi data panel digunakan untuk menganggar persamaan pertumbuhan. Keputusan penganggaran menunjukkan yang keterbukaan perdagangan mempunyai kesan positif keatas pertumbuhan ekonomi dan faedah marginal daripada keterbukaan perdagangan adalah lebih besar bagi ekonomi negara- negara Asia Timur berbanding dengan negara-negara lain di Asia.

\section{INTRODUCTION}

After the 1982 debt crisis, many countries, which had previously adopted inward oriented strategies, had shifted to outward-oriented strategies to promote economic growth. This change in strategy resulted from the observation that countries that adopt an open economic policy enjoy faster economic growth than countries that do not. This observation suggests openness can spur economic growth. Openness spurs economic growth, arguably, by positively influencing the productivity and efficiency of an economy.
Among developing regions, Asia has taken the lead in adopting outward-oriented development policies. Following a period of import substitution during the 1950s and 1960s, the newly industrialised economies (NIEs)-Hong Kong, China, Republic of Korea, Singapore, Taiwan, and a group of Southeast Asian economies-switched to an outward-oriented strategy. They encouraged exports, reduced import tariffs, and removed quantitative restrictions. Over time, they also dismantled barriers to capital inflows and outflows. 
In Southeast Asia, the commitment of ASEAN countries in liberalising trade is shown by the acceleration of the ASEAN Free Trade Area (AFTA) implementation date. They have decided that the target date for a free trade area in ASEAN should have been fully completed by the year 2002. ${ }^{1}$ They believe that the openness will regain business confidence, enhance economic recovery, and finally promote economic growth.

Previous literature on development economics stressed the special role of exports for economic growth (Balassa, 1978; Krueger, 1978; Edwards, 1992). These studies underlined the - various beneficial aspects of trade openness: greater capacity utilisation, resource allocation according to comparative advantage, exploitation of economies of scale, technological improvements, efficient management in response to competitive pressures abroad, and so on. These studies also proposed that since there are substantial differences in productivities between export-oriented and non-export oriented industries, countries that have adopted exportoriented policies benefit from closer-to-optimal resource allocation and higher growth (see Edwards, 1993, for the survey).

The importance placed on openness is so great that the World Bank, the International Monetary Fund and other multilateral institutions have routinely required the developing countries to embark on trade liberalisation and to open up their external sector as a condition for receiving financial assistance. However, some economists argued otherwise. For example, Sachs (1987) questioned the notion that trade liberalisation is a necessary component of successful outwardoriented strategies. He argued that the success of East Asian countries was to a large extent due to an active role of their governments in promoting exports in an environment where imports had not been fully liberalised. Taylor (1991) offered a much stronger view. He argued that the benefits of following open trade and capital market strategies are minimal while development strategies oriented internally may be a wise choice towards meeting a country's need.

In clarifying the causal relationship between trade openness and economic growth, one can provide policy recommendations. For example, if evidence suggests that greater trade openness induces faster economic growth, this supports granting a higher priority to those reforms that improve the trade openness of the economy. On the other hand, if openness is unrelated to economic growth, then lower priority should be given to this factor in any reform measures. Hence, it is the objective of the paper to investigate the relationship between trade openness and economic growth and determine whether this relationship varies across countries in the Asian region. To achieve this, an estimated growth equation using the econometrics panel data approach was used.

The rest of the paper is organised as follows. Section 2 displays the growth-openness relation in the Asian region. Section 3 reviews the existing literature on openness and economic growth. Section 4 presents the methodology employed in analysing the relation between trade openness and economic growth. Section 5 contains the empirical results, while Section 6 concludes.

\section{TRADE OPENNESS AND ECONOMIC GROWTH}

Historically, the idea that international trade (openness) is an engine of growth first started ever since the days of Adam Smith. The idea, however, did not seem to be very popular as Protectionist theories which heavily relied on "Import substitution Industrialization (ISI)"2 strategies became dominant for decades. The majority of developing countries implemented industrialisation policies based on a very limited degree of international openness.

The period in the 1980's after the 1982 debt crisis was the turning point. Policy makers sensed that the inward oriented policies followed by the majority of developing nations since World War II were no longer sustainable. They had observed the poor performance of the Latin American countries, most of which had followed the ISI strategies, compared to the rapidly growing East Asian countries that had aggressively implemented outward-oriented strategies (Table 1). 
Table 1

GDP and Export Growth in Selected Countries

\begin{tabular}{lccc}
\hline Country & Annual GDP Growth & \multicolumn{2}{c}{ Growth in Export } \\
\hline & Rates: $1960-94$ & 70 's & 80 's \\
\hline China & 6.8 & 8.7 & 11.9 \\
Indonesia & 5.7 & 7.2 & 5.6 \\
Korea & 8.5 & 23.5 & 11.9 \\
Malaysia & 7.0 & 4.8 & 11.3 \\
Hong Kong & 5.5 & 9.7 & 5.0 \\
Singapore & 8.3 & 4.2 & 9.9 \\
Thailand & 7.7 & 10.3 & 14.7 \\
India & 3.1 & 4.3 & 5.9 \\
Argentina & -0.9 & 7.1 & 2.2 \\
Mexico & -0.2 & 13.5 & 1.6 \\
Brazil & 0.4 & 8.5 & 5.0 \\
Chile & 3.7 & 10.4 & 5.5 \\
Egypt & 1.8 & -2.6 & 3.1 \\
Ivory Coast & -4.7 & 4.7 & 7.6 \\
Nigeria & -0.4 & 0.4 & 1.7 \\
Tanzania & 0 & -7.5 & -1.2 \\
Spain & 2.9 & 9.1 & 8.2 \\
Turkey & 2.9 & 4.3 & 9.0 \\
Japan & 3.6 & 9.0 & 4.6 \\
US & 1.7 & 6.5 & 3.8 \\
Germany & 2.4 & 5.0 & 4.6 \\
\hline
\end{tabular}

Sources: World Bank and World Development Report, various issues

The spectacular growth of many economies in East Asia (particularly Hong Kong, Korea, Singapore and Taiwan, followed by China, Indonesia, Malaysia, and Thailand) over the past 30 years provides a strong argument for exportled growth. The spectacular growth rates enjoyed by these economies improved their standards of living to be comparable with those of the rich industrialised countries. There appear to be a consensus that the success achieved by these economies is largely due to their unusual export performance, especially manufactured exports. Spectacular export performance not only allowed the high-performing Asian economies to reap economies of scale from expanding market size, it also gave them an ability to move to a new, higher production function typical of OECD countries. By offering countries opportunities to trade with the outside world, openness stimulates economic growth through easier access to new technologies and skills, and to investible resources in international capital markets (Asian Development Bank, 1999). At the same time, openness also promotes market discipline.

\section{REVIEW OF LITERATURE}

There has been a resurgence in interest on the role of international openness and international trade in influencing economic growth. The theoretical growth literature suggests that the relationship 
between trade restrictions and economic growth is not that straightforward. Various models have been developed in the endogenous growth literature in which trade restrictions can decrease or increase the worldwide rate of growth (Romer, 1990; Grossman \& Helpman, 1990). If trading countries are asymmetric in the sense that they have considerable technologies and endowments, even if dynamic integration raises the worldwide growth rate, it may adversely affect individual countries (Grossman \& Helpman, 1991; Young, 1991).

In the theory of international trade, the static gains from trade and losses from trade restrictions have been examined thoroughly. Yet, trade theory provides little guidelines as to the effects of international trade on growth and technical progress. On the contrary, the new trade theory makes it clear that the gains from trade can arise from several fundamental sources: differences in comparative advantage and economy-wide increasing returns.

Many empirical studies have been done to analyse the influence of openness on economic growth but the results are mixed. By using trade shares, which is exports plus imports divided by GDP, as a measure for openness, Balassa (1985), Edwards (1992), Frankel and Romer (1999), and Yanikkaya (2003) found a positive and strong relationship between openness and economic growth. However, the results of Irvin and Tervio's (2002) study indicated that the relationship between openness and economic growth when trade shares is used as a measure for openness is not robust to the inclusion of geographical - variables such as latitude and tropical climate.

A number of other studies have used trade barriers as a measure of trade openness. For example, using average tariff rates as a measure of openness, Lee (1993) and Harrison (1996) found a significant and negative relationship between tariff rates and growth. However, Edwards (1992) and Sala-i-Martin (1997) concluded that this relationship is weak. On the other hand, Rodrick (2001) and Yanikkaya (2003) found a positive relationship between import tariffs and economic growth.

Various studies have used the exchange rate as a measure for trade openness. The black market premium is frequently used to show the severity of trade restriction. Most of these studies reported a positive relationship between black market premium and growth (Harrison, 1996; Sala-i-Martin, 1997; Edwards,1998).

Some authors constructed indices of trade orientation to study the effect of trade openness on economic growth, e.g. Leamer's openness index (Leamer, 1988), Dollar's price distortion and variability indices (Dollar, 1992), and Sachs and Warner's openness index (Sachs \& Warner, 1995). Using these indices, they found a positive relationship between openness and economic growth. However, these indicators of openness are problematic and have serious shortcomings (Rodriguez \& Rodrik, 2001).

Using export growth as a measure of openness, Afxentiou and Serletis (1992) investigated the effect of openness on the Canadian economic development between 1870 and 1988. They found that over the period, openness Granger-caused GDP growth. Other studies that have use the same measure and achieved the same result are Bahmani-Oskooee, Mohtadi, and Shabsigh (1991) and Afxentiou and Serletis (2000). Similar studies have been done on ASEAN countries (Aggarwal, 1993; Ibrahim, 2002; Ngoc, Anh, \& Nga, 2003). While Aggarwal (1993) and Ibrahim (2002) found a positive correlation between export and economic growth, Ngoc et al. (2003) in their study on Vietnam found no evidence that export plays a leading role in generating economic growth.

Based on the above literature, we can make several conclusions. Firstly, there exists a large empirical literature providing mixed evidence on the issue of whether openness induces growth. However, a study on whether the effect is similar to all countries is still lacking. Secondly, different researchers have used many different measures of openness, methodologies, and sample countries, leading to results, which may differ for any number of reasons. Thirdly, the relationship between a number of openness measures and growth is not as robust. Our study differs from previous studies in Asian countries since we also studied whether the relationship varies across countries by using the panel data econometrics approach. In addition, our study also determines whether there is convergence in the Asian economies. 


\section{METHODOLOGY}

The relationship between trade openness and economic growth was examined by estimating a reduced-form equation relating the growth rate of real per capita GDP to an indicator of trade openness as one of the independent variables in the regression among the other variables used to control for other factors affecting growth. There does not exist a consensus on the theoretical framework to guide empirical work on growth, and existing models do not completely specify the variables that should be held constant while conducting statistical inference on the relationship between growth and the variables of primary interest (Levine \& Renelt, 1992). The framework for our model was developed by modifying a specification designed by Barro (1991) and further extended in Barro (1997). Our growth model -specification starts with the basic components of Barro's neoclassical growth model as explanatory variables. In selecting candidate variables for this study, particular attention was given to the variables identified by Levine and Renelt (1992) as robust: investment/GDP ratio and the initial evel of per capita GDP. This study will follow the approach adopted in many other previous studies (e.g. Barro, 1991; Levine \& Renelt, 1992) in that it is based on a regression of the reducedform:

Growth $=\alpha+\gamma I G D P+\phi O P E N N E S S+X \beta+\varepsilon$

- where Growth is a vector of the annual growth rate of GDP per capita. The rationale for using GDP per capita is for normalisation by taking into account the population, and suppressing this variable from the right hand side of the equation. The initial GDP per capita (IGDP) is included as an independent variable as adopted by Barro (1991), Edwards (1992), and Levine and Renelt (1992). The coefficient of IGDP per capita has been interpreted as a test of the convergence hypothesis; the neoclassical growth model predicts that per capita growth rates tend to be inversely related to IGDP per capita. Another interpretation suggested by Edwards (1992) is that countries with a lower initial per capita income have greater opportunities to "catch up" with more advanced nations. OPENNESS is a vector of the variable of primary interest, measured by the ratio of exports plus import to GDP, ratio of exports to GDP, and ratio of imports to GDP; $\boldsymbol{X}$ is a vector of variables to control for other factors affecting growth; and $\mathrm{e}$ is a white noise error term. There are many other measures of trade openness. Examples of these measures are an index of real exchange rate distortion, an index of exchange rate variability, average tariffs, and percentage of imports covered by non-tariff barriers as discussed in the literature review. However, this paper resorted to the ratio of exports and imports to GDP as used by Summers and Heston (1991), since it is the only measure of openness with a quantitative basis (Sinha \& Sinha, 1999) and the only viable choice for study that employs time-series data. In addition, the measure is free of bias regarding the size of the economy, allowing comparison over time between and within groups of countries as well as comparisons on country-specific biases (Farhang \& Edwards, 1997).

Open countries are argued to have greater access to new technologies, larger markets, and improved management technologies. They also tend to have fewer distortions and better allocation, and their firms are more likely to be competitive in world markets. However, trade openness can also adversely affect economic growth if imports comprised mainly of consumption goods with very little capital goods. Hence, the nett effects can only be determined empirically.

The control variables, $\mathrm{X}$, are crucial, since by including these variables, the strength of an independent link between trade openness and economic growth can be assessed. In this paper, these variables will be divided into two groups. The variables are significant determinants of growth as suggested by previous research (Levine \& Renelt, 1992; Sala-i-Martin, 1997; Ley \& Steel, 1999). These variables are the investment per GDP ratio, the size of government, inflation rate, school enrollment rate as a proxy for human capital accumulation, and growth rate of the working age population.

Investment per GDP ratio is the share of investment in the GDP of an economy which is a 
popular growth-determining factor and is used as a proxy for the growth rate of capital accumulation. The relationship is straightforward. Increases in investment will increase the rate of GDP growth.

The size of government measured by the share of government expenditure in the GDP serves as an indicator of macroeconomic stability, and is also designed to control for policy distortions in studying the relationship between trade openness and economic growth. The size of government can be either positively or negatively related to economic growth. On the one hand, a - government sector that is less efficient than the private sector may lead to slower growth. In addition, rent seeking activity and economic regulation may reduce economic efficiency and dissipate many of the benefits from government activity. On the other hand, if the government - provides an optimal level of public goods that would be unavailable if there were only private producers, then increased government activity may result in higher economic growth.

The growth rate of the working age population, measured by the growth rate of population between ages 16 and 64, is introduced - to pick up the role of demography in economic growth. Faster growth in the working age population causes faster economic growth by increasing the size of the working age population for a given increase in the population. School enrollment rate is used as a proxy for human capital accumulation. It is measured by the percentage of children between the ages of 6 to - 18 who are enrolled in primary and secondary schools. The rate of inflation was also included because past evidence indicates a strong connection between macroeconomic policy and economic activity (Fischer, 1993; Bruno \& Easterly, 1998).

A series of estimation techniques were employed. To control for country-specific individual effects, the model was specified as a panel data regression with fixed effects or random effects. The fixed-effects model assumes that slopes are common, but intercept vary across countries. On the other hand, the random-effects model assumes that intercepts are drawn from a common distribution and the error terms consist of two components: an error term unique to each observation and constant over time, and an error term representing the extent to which the intercept of a given cross-sectional unit varies from the overall intercept. Since the sample is drawn from a population (not all Asian countries are included in the sample due to data unavailability), it would be appropriate to assume that individual-specific intercepts are randomly distributed across crosssectional units. On the other hand, since this study focuses on Asian countries, it would also be reasonable to assume that the model is constant for the group of countries and thus the fixed-effect estimators are applicable.

\section{Sample and Data Sources}

The sample consists of 20 Asian countries based on the availability of data divided into two geographical regions; East Asian and non-East Asian. Countries included in the East Asian sample are China, Indonesia, Japan, Korea, Malaysia, Myanmar, Philippines, Singapore, and Thailand while countries included in the non-East Asian sample are Bangladesh, Bahrain, Egypt, Jordan, Kuwait, Iran, Sri Lanka, India, Nepal, Pakistan, and Syria.

All data are converted to US dollars by using each country's official exchange rate and then converted to real values using the individual country's GDP deflator. Both the country's official exchange rate and GDP deflator are obtained from various issues of the International Financial Statistics, International Monetary Fund. The dependent variable is the annual rate of growth in real GDP per capita averaged over each five year period and is calculated as (GDP per capita $t_{t}$ GDP per capita $\left._{t-1}\right) /$ GDP per capita ${ }_{t-1}$. Three measures of trade openness 1) ratio of exports plus imports to GDP, 2) ratio of exports to GDP, and 3) ratio of imports to GDP were used. Size of government is the ratio of government expenditures to GDP. The growth rate of the working age population is the growth rate of population between ages of 18 and 64. The inflation rate is the growth rate of the consumer price index. School enrollment rate is the percentage of children between the ages of 6 and 18 who are enrolled in primary and secondary schools. 
Data for GDP, Government Expenditure, Export, Import, Population, and Employment were obtained from various issues of the International Financial Statistics, International Monetary Fund, while data on school enrollment rate are from various issues of the Statistical Yearbook, UNESCO.

\section{RESULTS AND DISCUSSION}

Table 2 presents the descriptive statistics for all the explanatory variables used in our specification -(for the entire sample as well as for each of the East Asian and non-East Asian regions). Between 1975 and 2000, growth of per capita GDP averaged over $9.7 \%$ in East Asia compared to $9.1 \%$ in other Asian regions. Similarly, both domestic and foreign direct investments are much -higher in the East Asian countries compared to other Asian countries. Both the ratio of exports plus imports to GDP and the ratio of exports to imports are higher in East Asian countries, indicating the importance of trade to economic growth.

Table 3 shows the results of the panel data analysis for the set of 20 countries in Asia. Five separate five-year growth intervals were used covering the period $1975-2000$, for a total of 100 observations. Since the use of annual data would be clearly inappropriate for analysing the growth process and in any case would exhibit excessive noise (Khan \& Kumar, 1997), five-year period averages were selected as used in the growth literature. The dependent variable is the annual rate of growth in real GDP per capita averaged over each five-year period, which is explained by the independent variables, as defined above. There is concern that a simultaneity issue exists between GDP growth, trade openness and investment due to the interdependence between the variables. However, the F statistic for testing the hypothesis that trade openness and investment is exogenous could not be rejected. A Hausman test for correlation between the latent individual effect and the regressors can be used to verify whether the random-effect model is appropriate. If such correlation exists, then fixed effects estimation is the most appropriate technique, since its estimates are consistent and unbiased regardless of such correlation. The LM test is use to test for the significance of the country fixed-effects. The LM and Hausman statistics indicate that estimation using the country fixed-effects model is preferable to the pooled OLS (OLS on pooled cross sectional and time-series data) and random-effects models. Hence, this paper only reports the results of the country fixed-effects model.

Table 2

Summary Statistics of Sample Countries (1975-2000)

\begin{tabular}{lcccc}
\hline Variable & \multicolumn{3}{c}{ Sample } \\
\cline { 2 - 4 } & & All & East Asia & Others \\
Per Capita GDP Growth (\%) & 9.4 & 9.7 & 9.1 \\
Investment per GDP (\%) & 26.8 & 30.49 & 23.7 \\
Government Expenditure per GDP (\%) & 24.6 & 17.4 & 30.5 \\
Foreign Direct Investment per GDP (\%) & 2.4 & 2.6 & 2.3 \\
Government Debt per GDP (\%) & 5.6 & 8.0 & 3.7 \\
Ratio of Exports plus Imports to GDP & 1.4 & 1.6 & 0.8 \\
Ratio of exports to import & 0.93 & 1.01 & 0.86 \\
\hline
\end{tabular}

Source: from the author's calculation 
This fixed-effects approach includes time period and country specific dummy variables, such that full advantage of the panel data can be realised while controlling for any heterogeneity in the longitudinal and/or cross-sectional dimension of the panel data. Consequently, the results of the panel data estimation after correcting for heteroskedasticity using the White estimator of the variance-covariance matrix are presented. Equation 1 (Eq1), Equation 2 (Eq2), and Equation 3 (Eq3) are the equation when trade openness is measured by the ratio of exports plus imports to GDP, ratio of exports to GDP, and ratio of imports - to GDP respectively.

The adjusted R-squared statistic for Eq1 indicates that this specification explains about $41 \%$ of the total variation in the dependent variable. The coefficient of initial GDP, investment per GDP, and Inflation Rate are all statistically significant at the $5 \%$ level of significance and have the correct sign. However, the coefficient of Trade Openness measured by the ratio of exports plus imports to GDP, government expenditure per GDP, and the interaction term between Trade Openness and initial GDP are only significant at the $10 \%$ level of significance. In Eq2, when Trade Openness is measured by the ratio of exports to GDP, its coefficient becomes more significant. The same can also be said for initial GDP and the interaction term between Trade Openness and Initial GDP. On the other hand, when Trade Openness is measured by the ratio of imports to GDP, the coefficient is negative but not significant indicating that imports do not have any significant effects on economic growth.

Table 3

Panel Data Results of Growth Equation for All Sample (Dependent Variable: Average Annual Change in Real per capita GDP)

\begin{tabular}{lccc}
\hline Variable & $\mathrm{Eq} 1$ & $\mathrm{Eq} 2$ & $\mathrm{Eq} 3$ \\
\hline Log(Initial GDP) & $-0.0306^{* *}$ & $(-3.342)$ & $-0.0365^{* *}$ \\
& $(-3.825)$ & $-0.0228^{* *}$ & $(-2.612)$ \\
Trade Openness (Exports plus & $0.0616^{*}$ & & 0.0348 \\
Imports per GDP) & $(1.873)$ & & $(1.670)$ \\
& & & \\
Trade Openness (Exports per GDP) & & $0.0717^{* *}$ & \\
& & $(2.014)$ & \\
Trade Openness (Imports per GDP) & & & -0.0193 \\
& & & $(-0.610)$ \\
Investment per GDP & & & $0.0310^{* *}$ \\
& $0.0892^{* *}$ & $0.0076^{* *}$ & $(2.116)$ \\
Government Expenditure per GDP & $(2.194)$ & $(2.202)$ & $-0.0045^{*}$ \\
& $-0.0748^{*}$ & $-0.0012^{*}$ & $(-1.746)$ \\
School Enrollment Rate & $(-1.775)$ & $(-1.863)$ & \\
& & & $0.12 \mathrm{E}-05$ \\
Log(Foreign Direct Investment) & $0.68 \mathrm{E}-06$ & $0.19 \mathrm{E}-05$ & $(0.658)$ \\
& $(0.207)$ & $(0.882)$ & 0.0172 \\
& $0.0234^{*}$ & $0.0202^{*}$ & $(1.315)$ \\
& $(1.716)$ & $(1.693)$ &
\end{tabular}


(continued)

\begin{tabular}{lccc}
\hline Variable & Eq1 & Eq2 & Eq3 \\
\hline Inflation Rate & $-0.0121^{* *}$ & $-0.0131^{* *}$ & $-0.0151^{* *}$ \\
& $(-2.254)$ & $(-2.590)$ & $(-2.741)$ \\
Working Age Population Growth & -0.0797 & -0.2142 & -0.1768 \\
& $(-0.318)$ & $(-0.911)$ & $(-0.769)$ \\
Initial GDP*Trade Openness & $-0.0184^{*}$ & $-0.0902^{* *}$ & -0.0076 \\
& $(-1.739)$ & $(-2.492)$ & $(-1.293)$ \\
$\mathrm{R}^{2}$ & & & \\
Adjusted R & & 0.62 & 0.59 \\
F & 0.61 & 0.43 & 0.40 \\
LM & 0.41 & 3.36 & 3.08 \\
Hausman & 3.15 & 5.15 & 3.01 \\
Chow F statistic & 4.08 & 7.13 & 8.34 \\
No. of Observations & 8.47 & 2.13 & 2.26 \\
Figures in parenthesis are t-values & 1.71 & 100 & 100 \\
\hline
\end{tabular}

$* *$ significant at $5 \%$,

significant at $10 \%$

Based on equations 1 and 2 in Table 3 , the coefficient of trade openness shows that a $1 \%$ increase in openness will increase growth by $0.06 \%$ to $0.07 \%$. This indicates that openness to trade helps induce economic growth by utilising new technologies, providing larger markets, and improving managerial capabilities. Openness to trade also helps firms to be competitive in the international markets.

The coefficient of Initial GDP is negative and significant indicating that countries with smaller GDP tend to have higher economic growth relative to countries with higher GDP. This result implies that once the cross-country variation in other factors is taken into account, the poorer developing countries seem to have narrowed the gap between them and the richer countries, i.e. the case of conditional convergence. This is particularly true in the case of Malaysia, Thailand, Singapore, Korea, Taiwan, and Hong Kong where their standard of living have increased considerably relative to Japan.

The negative and significant coefficient of the interaction term between openness and initial GDP indicates that countries with a lower level of GDP have the potential to generate higher economic growth compared to countries with a higher level of GDP if their economy is more open to trade. That is, the marginal effect of Trade Openness on economic growth is higher for poorer countries. This supports the notion that, if the costs of technological imitation are lower than the costs of internally developed innovations, then a poorer country will grow faster than a more developed one. This faster rate of growth will continue as long as that country remains open to capturing new ideas until at some point, equilibrium is reached and the rate of growth slows.

Finally, this paper addresses whether any regional differences might exist between regions in Asia. This was done by using panel data analysis for each region separately, and in each case the same specification as Eq1, Eq2, and Eq3 was used (including both the time period and country specific dummy variables) to determine whether these effects were different across both regions separately. Due to the limited number of countries 
in our sample, we only divide the sample into East Asian and West/South Asian regions. Tables 4 and 5 present the regression results of the two regions respectively. From Eq1 in Table 4, the coefficients of initial GDP and Inflation Rate are both significant at the 5\% significance level and have the correct signs. Meanwhile, the coefficient of Trade Openness, Government Expenditure, and the interaction term between Trade Openness and initial GDP are all significant at the $10 \%$ level of significance and also have the correct sign. Using the ratio of exports to GDP as a measure of Trade Openness, the coefficient of initial GDP, Trade - Openness, and the interaction term between Trade
Openness and initial GDP becomes more significant, supporting the findings from the full sample regressions. When Trade Openness is measured by the ratio of imports to GDP, the coefficient of Initial GDP and Trade Openness also becomes more significant but the coefficient on Trade Openness becomes negative. This indicates that imports per se do not help in increasing economic growth (in fact imports are detrimental to growth from the Eq2 regression results). What is more important is the import of imports comprising of mostly investment goods, which are favourable for economic growth.

\section{Table 4}

Panel data Results of Growth Equation for East Asian Sample (Dependent Variable: Average Annual Change in Real per capita GDP)

\begin{tabular}{|c|c|c|c|}
\hline Variable & Eq1 & Eq2 & Eq3 \\
\hline Log(Initial GDP) & $\begin{array}{c}-0.0343 * * \\
(-4.359)\end{array}$ & $\begin{array}{c}-0.0365^{* *} \\
(-4.246)\end{array}$ & $\begin{array}{c}-0.0427^{*} \\
(-4.988)\end{array}$ \\
\hline $\begin{array}{l}\text { Trade Openness (Exports plus } \\
\text { Imports per GDP) }\end{array}$ & $\begin{array}{l}0.0094 * \\
(1.789)\end{array}$ & & \\
\hline Trade Openness (Exports per GDP) & & $\begin{array}{c}0.0807 * * \\
(2.517)\end{array}$ & \\
\hline Trade Openness (Imports per GDP) & & & $\begin{array}{c}-0.0499 * * \\
(-2.198)\end{array}$ \\
\hline Investment per GDP & $\begin{array}{l}0.0316^{*} \\
(1.864)\end{array}$ & $\begin{array}{c}0.3334 * * \\
(2.013)\end{array}$ & $\begin{array}{l}0.0499 * \\
(1.910)\end{array}$ \\
\hline Government Expenditure per GDP & $\begin{array}{c}-0.0296^{*} \\
(-1.753)\end{array}$ & $\begin{array}{c}-0.0217^{*} \\
(-1.712)\end{array}$ & $\begin{array}{c}-0.2015^{*} \\
(-1.797)\end{array}$ \\
\hline School Enrollment Rate & $\begin{array}{c}0.18 \mathrm{E}-05 \\
(1.007)\end{array}$ & $\begin{array}{c}0.24 \mathrm{E}-04 \\
(0.979)\end{array}$ & $\begin{array}{c}0.41 \mathrm{E}-05 \\
(0.732)\end{array}$ \\
\hline Log(Foreign Direct Investment) & $\begin{array}{l}0.0122 \\
(0.967)\end{array}$ & $\begin{array}{l}0.0211 \\
(0.849)\end{array}$ & $\begin{array}{l}0.0669 \\
(0.757)\end{array}$ \\
\hline Inflation Rate & $\begin{array}{l}-0.0158^{* *} \\
(-2.226)\end{array}$ & $\begin{array}{c}-0.01252^{*} \\
(-1.871)\end{array}$ & $\begin{array}{c}-0.0218^{* *} \\
(-3.272)\end{array}$ \\
\hline
\end{tabular}


(continued)

\begin{tabular}{lccc}
\hline Variable & Eq1 & Eq2 & Eq3 \\
\hline Working Age Population Growth & -0.0977 & -0.3131 & -0.1738 \\
& $(-0.944)$ & $(-0.438)$ & $(-0.286)$ \\
Initial GDP*Trade Openness & & & \\
& $-0.0262^{*}$ & $0.0217^{* *}$ & 0.0616 \\
$\mathrm{R}^{2}$ & $(-1.8006)$ & $(-2.608)$ & $(1.171)$ \\
Adjusted $\mathrm{R}^{2}$ & & & \\
F & 0.83 & 0.84 & 0.81 \\
LM & 0.67 & 0.69 & 0.65 \\
Hausman & 4.01 & 5.69 & 6.49 \\
No. of Observations & 4.08 & 3.86 & 3.81 \\
& 5.34 & 4.37 & 4.43 \\
\hline
\end{tabular}

Figures in parenthesis are t-values

* significant at $5 \%$,

* significant at $10 \%$

\section{Table 5}

Panel Data Results of Growth Equation for non East Asian Sample (Dependent Variable: Average Annual Change in Real per capita GDP)

\begin{tabular}{|c|c|c|c|}
\hline Variable & Eq1 & Eq2 & Eq3 \\
\hline Log(Initial GDP) & $\begin{array}{c}-0.0244 * * \\
(-2.004)\end{array}$ & $\begin{array}{c}-0.0245^{* *} \\
(-2.211)\end{array}$ & $\begin{array}{l}-0.0104 * \\
(-1.785)\end{array}$ \\
\hline $\begin{array}{l}\text { Trade Openness (Exports plus } \\
\text { Import per GDP) }\end{array}$ & $\begin{array}{l}0.0616 \\
(1.001)\end{array}$ & $\begin{array}{l}0.0484 \\
(1.305)\end{array}$ & \\
\hline Trade Openness (Exports per GDP) & & $\begin{array}{l}0.0484 \\
(1.305)\end{array}$ & \\
\hline Trade Openness (Imports per GDP) & & & $\begin{array}{l}0.0562 \\
(0.253)\end{array}$ \\
\hline Investment per GDP & $\begin{array}{c}0.0336 * \\
(1.815)\end{array}$ & $\begin{array}{c}0.0329 * \\
(1.901)\end{array}$ & $\begin{array}{c}0.0313^{*} \\
(1.785)\end{array}$ \\
\hline Government Expenditure per GDP & $\begin{array}{c}-0.0133^{*} \\
(-1.715)\end{array}$ & $\begin{array}{c}-0.0163 * \\
(-1.810)\end{array}$ & $\begin{array}{l}0.0604 * \\
(-1.695)\end{array}$ \\
\hline School Enrollment Rate & $\begin{array}{c}0.60 \mathrm{E}-04^{* *} \\
(2.147)\end{array}$ & $\begin{array}{c}0.53 \mathrm{E}-04^{*} \\
(1.960)\end{array}$ & $\begin{array}{c}0.20 \mathrm{E}-04^{*} \\
(1.679)\end{array}$ \\
\hline
\end{tabular}


(continued)

\begin{tabular}{lccc}
\hline Variable & Eq1 & Eq2 & Eq3 \\
\hline Log(Foreign Direct Investment) & 0.0210 & 0.0208 & 0.0197 \\
& $(0.637)$ & $(0.693)$ & $(0.594)$ \\
Inflation Rate & $-0.0412^{*}$ & $-0.0309^{*}$ & $-0.0746^{*}$ \\
& $(-1.721)$ & $(-1.747)$ & $(-1.745)$ \\
Working Age Population Growth & -0.1213 & -0.4407 & $-0.4578^{*}$ \\
& $(-1.036)$ & $(-1.370)$ & $(-1.905)$ \\
Initial GDP*Trade Openness & & & \\
& -0.0611 & $-0.0374 *$ & -0.0139 \\
& $(-1.473)$ & $(-1.767)$ & $(-0.494)$ \\
$\mathrm{R}^{2}$ & & & \\
Adjusted ${ }^{2}$ & 0.63 & 0.64 & 0.61 \\
F & 0.38 & 0.39 & 0.37 \\
LM & 3.50 & 3.56 & 3.43 \\
Hausman & 3.68 & 3.61 & 3.19 \\
No. of Observations & 4.22 & 4.25 & 4.13 \\
& 55 & 55 & 55 \\
\hline
\end{tabular}

Figures in parenthesis are $t$-values

** significant at $5 \%$,

* significant at $10 \%$

-

For the West and South Asian sample (the results in Table 5), although the coefficient of initial GDP is negative but significant in all of the equations, the coefficient of Trade Openness is the opposite. Although having the correct sign, the coefficient of Trade Openness on all measures and the interaction term between Trade Openness and initial GDP are both not significant. The results indicate that Trade Openness does not influence economic growth for countries in West and South Asia. This may be partly due to the heavy reliance on oil exports in the case of the West Asian countries and political instability for both West and South Asian countries which may not be beneficial for their economies. The results also show that the marginal benefit from improved openness is somewhat less for the West and South Asian countries. This result is very important. It supports the argument that, without introducing the appropriate internal policies and institutions, trade reform is not the magical solution. Countries that adopted a variety of internal growth-friendly policies and institutions, rather than trade per se, will promote growth. To determine whether both the West and South Asian countries samples can be pooled together, the Chow test was employed. The results of the Chow test indicated that the null hypothesis that coefficients are equal for both samples could not be rejected. Hence, pooling both samples is appropriate (See Table 3).

\section{CONCLUSION}

This paper attempts to empirically assess the role of trade openness in explaining differences across selected Asian countries in the level of real GDP growth. The results indicate that Trade Openness does have a positive effect on economic growth. The results also show that the Trade Openness variable becomes more significant in affecting GDP growth when it is measured by the ratio of 
exports to GDP, thus supporting the strategy of export-led growth. The findings support the idea of conditional convergence and higher marginal effect of trade openness on economic growth, indicating that convergence is faster in a more open nation. The results suggest that the lower income countries in Asia can catch-up to their richer counterparts provided that they aggressively pursue the strategy of export-led growth. The results also show that the marginal benefit from improved openness is somewhat higher for the East Asian Economies, relative to others possibly because of the more efficient use of resources from

outward-orientation and a stable political environment.

\section{END NOTES}

1. In 1998, ASEAN agreed to move forward with a free trade area by $2003-2008$. Under that agreement, the six founding ASEAN members (Brunei, Indonesia, Malaysia, the Philippines, Singapore, and Thailand) agreed from 1 January 2000 to reduce import tariffs on about $85 \%$ of agricultural and manufacturing goods to 5\% and implement a free trade area by 2002 . Less-developed ASEAN countries (Laos, Cambodia, Myanmar, and Vietnam) have until 2006-2008 to come into the fold.

Originated from the thinking of Raul Prebisch (Prebisch, 1950) and Hans Singer (Singer, 1950). A policy of import substitution for industrialisation purposes (ISI) involves extensively controlling virtually all components of the economy in order to direct resources into manufacturing.

The approach of many empirical studies on economic growth is: firstly, calculate the growth rate over time for each economy; secondly, across economies, regress this average growth rate on conditioning variables, such as - trade openness, schooling, investment, government spending, political circumstances - and on initial income. The underlying idea of the procedure is that the conditioning variables explain the permanent growth component or trend, while the initial condition controls for transitory dynamics.

\section{REFERENCES}

Afxentiou, P. C. \& Serletis A. (1992). Openness in the Canadian Economy: 18701988, Applied Economics, 24(11), 11911198.

Afxentiou, P. C. \& Serletis, A. (2000). Output Growth and variability of export and import growth: International evidence from Granger Causality Tests, The Developing Economies, 38(2), 141-163.

Aggarwal, M. R. (1993). Exports and Total Capital Inflows as Sources of ASEAN Economic Dynamism. ASEAN Economic Bulletin, 10(1), 20-39.

Asian Development Bank (1999). Asian Development Outlook 1999, Manila: Asian Development Bank.

Bahamni-Oskooee, M., Mohtadi H. \& Shabsigh G. (1991). Exports, growth and causality in LDCs: a reexamination. Journal of Development Economics, 36(2), 405415.

Balassa, B. (1978). Exports and Economic Growth: Further Evidence. Journal of Development Economics, 5(2), 181-189.

Balassa, B. (1985). Exports, Policy Choices, and Economic Growth in Developing Countries after the 1973 Oil Shock. Journal of Development Economics, 18, 23-35.

Barro, R. J. (1991). Economic Growth in a Crosssection of Countries. Quarterly Journal of Economics, 106, pp. 407-433.

Barro, R. J. (1997). Determinants of Economic Growth: A Cross-country Empirical Study. Cambridge: MIT Press.

Bruno, M. \& Easterly W. (1998). Inflation Crises and Long-run growth. Journal of Monetary Economics, 41(1), 3-26. 
Collins, S. M. \& Bosworth, B. P. (1996). Economic Growth in East Asia: Accumulation Versus Assimilation. Brookings Papers on Economic Activity, 2, pp. 135-303.

Dollar, D. (1992). Outward-oriented developing economies really do grow more rapidly: evidence from 95 LDCs, 1976-1985. Economic Development and Cultural Change, 40, 523-544.

Edwards, S. (1992). Trade Orientation, Distortions, and Growth in Developing Countries, Journal of Development Economics, 39, 31-57.

Edwards, S. (1993a). Openness, Trade Liberalization, and Growth in Developing Countries, Journal of Economic Literature. Vol. XXXI, 13581393.

Edwards, S. (1993b). Trade Policy, Exchange Rates and Growth. NBER Working Paper No. W4511.

Edwards, S. (1998). Openness, Productivity and growth: what do we really know? Economic Journal. 108, 383-398.

Fischer, S. (1993). The Role of Macroeconomic Factors in Growth. Journal of Monetary Economics. 32, 485-512.

Farhang, N. \& Edwards, N. (1997). An inquiry into openness in International Trade, Journal of Economic Studies, 24(3), 167181.

Frankel, J. A. \& Romer, D. (1999). Does Trade Cause Growth, American Economic Review, 89, 379-399.

Grossman, G. M. \& Helpman, E. (1990). Comparative Advantage and Long-run Growth, American Economic Review, 80, 796-815.
Grossman, G. M. \& Helpman, E. (1991). Quality Ladders in the Theory of Growth, Review of Economic studies, 58, 43-61.

Harrison, A. (1996). Openness and Growth: a time series, cross-country analysis for developing countries. Journal of Development Economics, 48, 419-447.

Ibrahim, I. (2002). On Exports and Economic Growth. Jurnal Pengurusan, 21, 3-19.

Irvin, D. A. \& M. Tervio, M. (2002). Does Trade Raise Income? Evidence From the Twentieth Century. Journal of International Economics, 58, 1-18.

Khan, M. S. \& Kumar, M. S. (1997). Public Investment, Productivity, and Economic Growth in Developing Countries, Journal of Public Budgeting, Accounting and Financial Management, 9(3), pp. 4440-466.

Krueger, A. O. (1978). Foreign Trade Regimes and Economic Development: Liberalization Attempts and Consequences. Cambridge, MA: Bollinger.

Leamer, E. E. (1988). Measures of openness. In R. E. Baldwin, (Ed.), Trade policy issues and empirical analysis. Chicago: The University of Chicago Press, 147-204.

Lee, J. W. (1993). International Trade, distortions, and long-run economic growth. IMF Staff Papers, 40(2), 299-328.

Levine, R. \& Renelt, D. (1992), A Sensitivity Analysis of Cross-Country Growth Regressions. American Economic Review, 4, 942-963.

Ley, E. \& Steel, M. F. J. (1999). We Just Averaged Over Two Trillion Cross-country Growth Regressions. IMF Working Paper no. 101. 
Ngoc, P. M., Anh, N. T. P., \& Nga, P. T. (2003). Exports and Long-run Growth in Vietnam, 1975-2001. ASEAN Economic Bulletin, 20(3), 211-232.

Prebisch, R. (1950). The Economic development of Latin America and its Principal Problems. New York: United Nations.

Rodrik, C. (2001). Trading in Illusions. Foreign Policy, 123, 54-63.

Rodriguez, F. \& Rodrik, D. (2001). Trade Policy - and Economic Growth: A Skeptic's Guide to the Cross-National Evidence, NBER. In B. Bernanke \& K. S. Rogoff, (Eds.). NBER Macroeconomics Annual 2000. Cambridge MA: MIT Press.

Romer, P. M. (1990). Endogenous Technical Change. Journal of Political Economy, 98, S71-S102.

Sachs, J. D. (1987). Trade and Exchange Rate Policies in Growth-oriented Adjustment Programs. In V. Corbo, M. Goldstein, \& M. Khan (Eds.). Growth-oriented Adjustment Programs. Washington D.C.: IMF.

Sachs, J. D. \& Warner, A. M. (1995). Economic reform and the process of economic integration. Brookings Papers of Economic Activity, 2, 1-118.
Sala-i-Martin, X. (1997). I Just Ran Two Million Regressions, American Economic Review, 87, 178-183.

Singer, H.W. (1950). The Distribution of Gains Between Investing and Borrowing Countries. American Economic Review, 40(2), pp. 473-485.

Sinha, T. \& Sinha, D. (1999). The Relation Between Openness and Economic Growth: Postwar Evidence From 124 Countries. Seoul Journal of Economics, 12(1), 67-84.

Summers, R. \& Heston, A. (1991). The Penn World Table (Mark 5): An Expanded Set of International Comparisons 1950-88. Quarterly Journal of Economics, 106, 327-368.

Taylor, L. (1991). Economic Openness: Problems to the Century's End. In T. Banuri (Ed.), Economic Liberalization: No Panacea. Oxford: Oxford University Press, 99147.

Yanikkaya, H. (2003). Trade Openness and Economic Growth: a cross-country empirical investigation. Journal of Development Economics, 72, 57-89.

Young, A. (1991). Learning by doing and the Dynamic Effects of International Trade. Quarterly Journal of Economics, 106, 369-405. 